\title{
Eucalyptus essential oils inhibit the lipopolysaccharide-induced inflammatory response in RAW264.7 macrophages through reducing MAPK and NF-KB pathways
}

Chen-Lung Ho ${ }^{1}$, Lan-Hui Li2 ${ }^{2,3}$, Yueh-Chun Weng ${ }^{4}$, Kuo-Feng Hua ${ }^{3,5,6}$ and Tz-Chuen Ju ${ }^{7 *}$ (D)

\begin{abstract}
Background: Eucalyptus essential oils have been used in traditional medicine for centuries. It was reported that Eucalyptus leaves possess antioxidant and antimicrobial effects. Here, we investigated the anti-inflammatory activity of the essential oils extracted from the leaves of four different Eucalyptus species in RAW264.7 macrophages.

Methods: Lipopolysaccharide (LPS)-activated RAW264.7 macrophages were used to evaluate the anti-inflammatory activity of the leaf essential oils of Eucalyptus. The cell survival was quantified by an Alamar Blue assay. Nitric oxide (NO) production was assessed by Griess reaction. TNF-a and IL-6 production were measured by enzyme-linked immunosorbent assay (ELISA). Nuclear factor-KB (NF-KB) transcriptional activity was measured by NF-KB reporter assay. Intracellular protein expression levels were determined by Western blot. The expression levels of inducible NO synthase (iNOS), cyclooxygenase-2 (COX-2), mitogen-activated protein kinase (MAPK), protein kinase C (PKC) and NF-kB pathway were measured by western blot in LPS-activated RAW 264.7 macrophage.

Results: The essential oils extracted from Eucalyptus citriodora leaf exert the best NO inhibitory activity in LPSactivated RAW264.7 macrophages. The essential oils were fractionated into fractions $\mathrm{A}-\mathrm{H}$, and fraction $\mathrm{F}$ has been demonstrated to inhibit the expression levels of TNF-a, IL-6, NO, iNOS and COX-2 in LPS-activated RAW264.7 macrophages. Mechanistic analysis revealed that fraction $\mathrm{F}$ reduced the phosphorylation levels of ERK1/2, p38, PKC$a, P K C-\varepsilon$ and PKC- $\delta$, and inhibited the NF-KB transcriptional activity. The chemical composition of Fraction $F$ was determined by GC-MS.

Conclusions: The discoveries made herein could help develop innovative nonsteroidal anti-inflammatory drugs with minimal side effects and strong efficacy. Clinical trials on these Eucalyptus leaf essential oils will help customize and optimize their therapeutic administration.
\end{abstract}

Keywords: Anti-inflammation, Eucalyptus essential oils, Macrophages, Cytokine, Lipopolysaccharide

\footnotetext{
* Correspondence: tzchuen@thu.edu.tw

${ }^{7}$ Department of Animal Science and Biotechnology, Tunghai University, No.

1727, Sec. 4, Taiwan Blvd., Xitun Dist, Taichung City 40704, Taiwan

Full list of author information is available at the end of the article
}

(C) The Author(s). 2020 Open Access This article is licensed under a Creative Commons Attribution 4.0 International License, which permits use, sharing, adaptation, distribution and reproduction in any medium or format, as long as you give appropriate credit to the original author(s) and the source, provide a link to the Creative Commons licence, and indicate if changes were made. The images or other third party material in this article are included in the article's Creative Commons licence, unless indicated otherwise in a credit line to the material. If material is not included in the article's Creative Commons licence and your intended use is not permitted by statutory regulation or exceeds the permitted use, you will need to obtain permission directly from the copyright holder. To view a copy of this licence, visit http://creativecommons.org/licenses/by/4.0/ The Creative Commons Public Domain Dedication waiver (http://creativecommons.org/publicdomain/zero/1.0/) applies to the data made available in this article, unless otherwise stated in a credit line to the data. 


\section{Background}

Eucalyptus trees are in the genus Eucalyptus of the Myrtaceae. There are $>700$ Eucalyptus tree species worldwide [1]. They originated in Australia and Indonesia. The wood is used for pulp, fiber, fuel, furniture and construction. The essential oils are distilled from the leaves and used for medicinal purposes. Eucalyptus trees grow rapidly and adapt well to their surroundings. They were introduced into Taiwan in the 1980s primarily as sources of pulp for papermaking. Eucalyptus essential oils are widely used in traditional cold, fever and bronchitis remedies [2]. Vapor inhalation and oral ingestion of Eucalyptus essential oils treat suppurative and general respiratory tract infections such as asthma and chronic obstructive pulmonary disease (COPD) [3]. Previous research found that Eucalyptus essential oils inhibit Trypanosoma [4]. Lemon Eucalyptus essential oil has strong efficacy against Amblyomma cajennense and Anocentor nitens [5]. The essential oils in Eucalyptus leaves have antiseptic efficacy against Escherichia coli and Staphylococcus aureus [6]. Salem et al. proposed that essential oils from E. citriodora possesses strong bactericidal and fungicidal activities [7]. Eucalyptus essential oils are immunoregulatory, anti-inflammatory, antioxidant and analgesic. They also enhance the phagocytic capacity of monocytes and macrophages [3]. The essential oils from E. camaldulensis kill Aedes aegypti and A. albopictus larvae [1]. Eucalyptus essential oils neutralize free radicals and reactive oxygen species (ROS) [8]. Essential oils from E. citriodora, E. globulus and E. tereticornis also exert analgesic and anti-inflammatory activity [2].

Bacterial infections trigger immune responses in the human body and large amounts of proinflammatory substances are released. Moderate inflammatory reactions activate immune cells that kill pathogens and protect the body. However, excessive inflammatory reactions cause rapid cell death and lower blood pressure which results in ischemia, tissue necrosis, organ failure and death. Thus, controlling inflammatory reactions is a medical priority. Inflammatory reactions protect the body against pathogens but may also injure surrounding tissue [9]. Whereas mild inflammatory reactions are beneficial and protective, severe inflammation may be destructive as it induces high fever, delirium and sepsis. Early acute inflammatory reactions are generally resolved after healing. However, they may persist and become chronic if they are dysregulated. Chronic inflammation may cause and/ or exacerbate atherosclerosis [10], diabetes [11], aging [12], neurodegeneration [13], and cancer [14].

Inflammation is therapeutically controlled mainly by steroidal and nonsteroidal anti-inflammatory drugs (NSAIDs). The former has numerous serious side effects and may induce and/or exacerbate hypertension, diabetes, glaucoma, hypertension, dermal atrophy, myopathy, hirsutism, insomnia, depression and mental illness. In contrast, the side effects of NSAIDs are relatively minor and may include gastrointestinal distress or inflammation. In severe cases, NSAIDs may cause GI perforation, peptic ulcers and hemorrhage. Current research has focused on the discovery of natural nonsteroidal anti-inflammatory fractions with minimal side effects and yet maximal efficacy. In the present study, an in vitro cell culture model was used to examine the influences of Eucalyptus essential oils on inflammatory reactions in macrophages. Other objectives were to identify the mutually interacting signal transduction pathways involved in these inflammatory reactions and determine whether Eucalyptus essential oils could mitigate the inflammatory response by modulating these biomolecular mechanisms.

Eucalyptus essential oils have been used in traditional medical treatments for centuries. They have been extensively studied and are valued for their comparatively low toxicity and broad-spectrum antiseptic activity [3, 6]. Here, we examined the anti-inflammatory activity of the essential oils extracted by water distillation from the leaves of E. urophylla, E. grandis, E. camaldulensis and E. citriodora. Lipopolysaccharides (LPS) were applied to RAW264.7 murine macrophages to trigger inflammatory reactions. We first screened the four types of Eucalyptus essential oils based on their inhibition of nitric oxide (NO) generation. The most active essential oil will be subjected to chromatographic analysis. Next, we tested the anti-inflammatory activity and elucidate the mechanisms by which they suppress the inflammatory response.

\section{Methods \\ Plant materials}

Fresh leaves of Eucalyptus urophylla, Eucalyptus grandis and Eucalyptus camaldulensis were collected in August 2017 from the Kukeng Experimental Plantation of the Taiwan Forestry Research Institute (TFRI) in southcentral Taiwan (Yunlin County, elevation $100 \mathrm{~m}, \mathrm{~N} 23^{\circ}$ $\left.62^{\prime} 58^{\prime \prime}, 120^{\circ} 57^{\prime} 20^{\prime \prime}\right)$, while fresh leaves of Eucalyptus citriodora were collected in August 2019 from the Lienhwachih Research Center, TFRI in central Taiwan (Nantou County, elevation $500 \mathrm{~m}, \mathrm{~N} \mathrm{23^{ \circ }} 91^{\prime} 75^{\prime \prime}, 120^{\circ}$ $\left.88^{\prime} 52^{\prime \prime}\right)$. The samples were compared with specimen No. E-0032, E-0033, E-0034 and E-0035 from the herbarium of National Chung Hsing University $(\mathrm{NCHU})$ and were positively identified by Prof. Yen-Hsueh Tseng of NCHU. The voucher specimen (CLH-068, CLH-069, CLH-070 and CLH-071) were deposited in the NCHU herbarium. The collected leaves were immediately shipped to our Taipei headquarters, and the essential oils were extracted for subsequent analyses. 


\section{Extraction of the leaf essential oils}

A sample of $1 \mathrm{~kg}$ of fresh leaves from each species was placed in a round-bottomed flask, and $3 \mathrm{~L}$ of distilled water was added. After $8 \mathrm{~h}$ of steam distillation, the oil layers had separated from the water layers and were collected, and anhydrous sodium sulfate was added to eliminate the water. We repeated the isolation procedure for 4 times and combined the leaf essential oil for further fractionation. Yields of the essential oils were determined and the oils were stored in specimen bottles. Yields of leaf essential oils of E. urophylla, E. grandis, E. camaldulensis and E. citriodora were $3.18 \pm 0.05,2.98 \pm$ $0.06,3.58 \pm 0.07$, and $1.98 \pm 0.08 \mathrm{ml} / 100 \mathrm{~g}$, respectively.

\section{Fractionation of the leaf essential oil of E. citriodora}

Fifty grams of E. citriodora leaf oil was mixed with $100 \mathrm{~g}$ silica gel (Merck 7734, Merck Co., Germany), separated on a silica gel open column $(1000$ g, $85 \mathrm{~mm}$ i.d., $850 \mathrm{~mm}$ length), and then eluted with a step gradient of n-hexane and ethyl acetate that ranged from n-hexane/ethyl acetate $=100: 0-0: 100$. The fractions were collected by thin layer chromatography (TLC) and visualized at UV 254 $\mathrm{nm}$ and UV $366 \mathrm{~nm}$, with iodine vapor and 1\% vanillin/ $\mathrm{H}_{2} \mathrm{SO}_{4}$. The band fractions from the leaf oil that contained the same compounds were combined to produce 8 sub-fractions: fractions A (5.3\%), B (7.6\%), C (11.5\%), D (9.8\%), E (10.2\%), F (35.2\%), G (18.1\%), and H (2.3\%).

\section{Gas chromatography-mass spectrometry (GC-MS) analysis of fractions $F$ and $G$}

A Hewlett-Packard HP 6890 gas chromatograph equipped with a DB-5 fused silica capillary column (30 $\mathrm{m} \times 0.25 \mathrm{~mm} \times 0.25 \mu \mathrm{m}$ film thickness, J\&W Scientific) and a FID detector were used for the quantitative determination of the chemical compositions of fractions $\mathrm{F}$ and G. Samples were incubated in an oven at $50^{\circ} \mathrm{C}$ for $2 \mathrm{~min}$, and then the temperature incrementally increased to $250^{\circ} \mathrm{C}$ at $5{ }^{\circ} \mathrm{C} / \mathrm{min}$. The injection temperature was $270{ }^{\circ} \mathrm{C}$. The carrier gas was helium and had a $1 \mathrm{ml} / \mathrm{min}$ flow rate. The detector temperature was $250{ }^{\circ} \mathrm{C}$, with a split ratio of 1:10. The injection volume was $1 \mu$ l. Identification of the oil components was based on their retention indices and mass spectra obtained from GC-MS analysis on a Hewlett-Packard HP 6890/HP5973 equipped with a DB-5 fused silica capillary column (30 $\mathrm{m} \times 0.25 \mathrm{~mm} \times 0.25 \mu \mathrm{m}$ film thickness, J\&W Scientific). The MS reuslts were obtained in full scan mode with a $0.3 \mathrm{~s}$ scan time and a mass range of $\mathrm{m} / \mathrm{z} 30-500$ in the EI mode at $70 \mathrm{eV}$. All data are presented as the average of experiments performed in triplicate. Identification of the chemical compositions of fractions $F$ and $G$ was based on comparisons of Kovats index (KI), retention times (RT), and mass spectra with those obtained from authentic standards and/or the NIST and Wiley libraries spectra, and literature, respectively. The $\mathrm{F}$ and $\mathrm{G}$ fractions were identified using their Kováts retention indices calculated for all volatile constituents using a homologous series of n-alkanes C9-C23 on DB-5MS column, and comparing sample mass spectra with those obtained from authentic standards and/or the NIST and Wiley libraries spectra, and the literature [15].

\section{Materials}

Antibodies against PKC- $\alpha, \mathrm{PKC}-\varepsilon$ and PKC- $\delta, \mathrm{COX} 2$, pIKK- $\alpha$ and anti-p-IкB- $\alpha$ were procured from Santa Cruz Biotechnology (Dallas, TX). Antibodies against p-ERK1/ 2, p-JNK1/2 and p-p38 were purchased from Cell Signaling Technology (Danvers, MA). Antibodies against iNOS and $\beta$-actin, lysis buffer and polyvinylidene fluoride (PVDF) membrane were purchased from EMD Millipore (Bedford, MA). LPS (Escherichia coli O111:B4) and protease/phosphatase inhibitor cocktail were purchased from Sigma-Aldrich (St. Louis, MO). Enzyme-linked immunosorbent assay (ELISA) kits and enhanced chemiluminescence (ECL) reagents were purchased from Thermo Fisher Scientific (Waltham, MA). RPMI 1640 was purchased from Gibco Laboratories (Grand Island, NY, USA). Fetal bovine serum (FBS) was purchased from Biological Industries Ltd. (Kibbutz Beit Ha-emek, Israel). L-glutamine was purchased from Life Technologies (Carlsbad, CA, USA). Alamar Blue assay kit was purchased from AbD Serotec (Oxford, UK). QUANTIBlue medium was purchased from InvivoGen (San Diego, CA).

\section{Cell cultures}

RAW264.7 macrophage were purchased from the American Type Culture Collection (Rockville, MD). RAW-Blue macrophages were purchased from InvivoGen (San Diego, CA). All cells were propagated in RPMI 1640 supplemented with $10 \% \quad(\mathrm{v} / \mathrm{v})$ heatinactivated $\mathrm{FBS}$ and $2 \mathrm{mML}$-glutamine at $37^{\circ} \mathrm{C}$ in a $5 \% \mathrm{CO}_{2}$ incubator $[16,17]$.

\section{Cell viability assay}

Cell death was quantified by the MTT reduction assay.

Cell viability was quantified by the Alamar Blue assay. Breifly, RAW264.7 macrophages were incubated with or without tested sample for $24 \mathrm{~h}$. Alamar Blue reagent $(10 \mu \mathrm{l})$ was added into the culture medium and incubated at $37^{\circ} \mathrm{C}$ in a $5 \% \mathrm{CO}_{2}$ incubator for $2-3 \mathrm{~h}$. Fluorescence was detected with a fluorescence microplate reader (excitation/emission: $570 \mathrm{~nm} / 600 \mathrm{~nm}$; OPTImax tunable plate reader; Molecular Devices, Sunnyvale, CA, USA). 


\section{NO production assay}

RAW264.7 macrophages were incubated for $0.5 \mathrm{~h}$ with tested samples, followed by incubated with or without $1 \mu \mathrm{g} / \mathrm{ml}$ LPS for $24 \mathrm{~h}$. NO levels in the culture medium were measured by the Griess reaction as described previously [17].

\section{Western blot analysis}

Western blot was performed as described previously [16, 17]. Briefly, protein was extracted with a protease and phosphatase inhibitor cocktail containing lysis buffer. The lysates were electrophoretically fractionated through $10 \%$ SDS-polyacrylamide gel and then electrotransferred onto PVDF membranes. The membranes were incubated for $1 \mathrm{~h}$ at room temperature in $5 \%(\mathrm{v} / \mathrm{v})$ nonfat milk in phosphate-buffered saline (PBS) with $0.1 \%(\mathrm{v} / \mathrm{v})$ Tween20). The primary antibodies were applied to the blots and incubated for $2 \mathrm{~h}$ at room temperature, followed by secondary antibody for $1 \mathrm{~h}$ at room temperature. The immunoreactive signals were detected with ECL reagents.

\section{NF-KB reporter assay}

The NF- $\kappa B$ reporter assay was conducted as described previously $[16,17]$. Briefly, RAW-Blue cells $\left(10^{5}\right.$ cells per $0.5 \mathrm{ml}$ medium) were treated for $0.5 \mathrm{~h}$ with $12.5 \mu \mathrm{g} / \mathrm{ml}$, $25 \mu \mathrm{g} / \mathrm{ml}, 50 \mu \mathrm{g} / \mathrm{ml}$ or $100 \mu \mathrm{g} / \mathrm{ml}$ Fraction F, followed by incubated with or without $1 \mu \mathrm{g} / \mathrm{ml}$ LPS for $24 \mathrm{~h}$. The harvested medium $(20 \mu \mathrm{l})$ was mixed with $200 \mu \mathrm{l}$ QUANTI-Blue medium in 96-well plates and incubated at $37^{\circ} \mathrm{C}$ for $2 \mathrm{~h}$. SEAP activity was measured at $655 \mathrm{~nm}$ in an ELISA microplate reader (Bio-Tek Instruments, Winooski, VT, USA).

\section{ELISA assay}

RAW264.7 macrophages ( $10^{5}$ cells per $0.5 \mathrm{ml}$ medium) were treated for $0.5 \mathrm{~h}$ with tested sample, followed by incubation with or without $1 \mu \mathrm{g} / \mathrm{ml}$ LPS for $24 \mathrm{~h}$. The levels of TNF- $\alpha$ and IL- 6 in the culture medium were measured by ELISA according to the manufacturer's protocol. Briefly, the 96-well microplates were coated overnight with anti-TNF- $\alpha$ or anti-IL-6 antibody, blocked with $1 \%(\mathrm{v} / \mathrm{v})$ bovine serum albumin (BSA) in PBS, and washed repeatedly. Samples or standards $(100 \mu \mathrm{l})$ were added to the microplates, incubated at room temperature for $2 \mathrm{~h}$, washed repeatedly, incubated for $2 \mathrm{~h}$ with biotin-conjugated detection antibody, and incubated for $30 \mathrm{~min}$ with $100 \mu \mathrm{l}$ streptavidinhorseradish peroxidase (HRP) plus substrate for signal development. Then $100 \mu \mathrm{l}$ stop solution was added to each well and the $\mathrm{OD}_{450}$ were measured in an ELISA microplate reader (Bio-Tek Instruments, Winooski, VT, USA) [16, 17].

\section{Statistical analysis}

Data were expressed as means \pm standard deviation (SD) of triplicate samples. Each experiment was repeated at least three times to confirm reproducibility. Multiple groups were analyzed with one-way analysis of variance (ANOVA), followed by a post hoc Student-NewmanKeuls test. Differences among treatment means were considered statistically significant when $P<0.05$.

\section{Result \\ Effects of leaf essential oils from different Eucalyptus species on NO generation and cell viability}

NO shows a crucial role in LPS-induced inflammatory reactions in macrophages. Thus, we evaluated the effect of the leaf essential oils extracted from E. citriodora, $E$. grandis, E. urophylla and E. camaldulensis on NO production in LPS-activated macrophages. RAW264.7 macrophages were incubated with or without 25,50 or $100 \mu \mathrm{g} / \mathrm{ml}$ essential oils for $0.5 \mathrm{~h}$ followed by LPS stimulation for $24 \mathrm{~h}$ (each group containing $0.1 \%$ DMSO in the cultural medium). We found that leaf essential oils from E. grandis and E. citriodora reduced the NO production in a dose dependent manner, while $E$. citriodora was potent than $E$. grandis. However, LPS-induced NO production was not affected by leaf essential oils from $E$. urophylla and E. camaldulensis (Fig. 1a). We next investigated the influences of four leaf essential oils on the cell viability by Alamar Blue assay. RAW264.7 macrophages were incubated with or without 25,50 or $100 \mu \mathrm{g} /$ $\mathrm{ml}$ essential oils for $24 \mathrm{~h}$. We found that leaf essential oils from $E$. citriodora and $E$. grandis reduced RAW264.7 macrophages viability in a dose dependent manner; however, the viability was not significantly reduced by the leaf essential oils from E. urophylla and $E$. camaldulensis (Fig. 1b).

\section{Subfractions of $E$. citriodora leaf essential oils inhibited NO generation}

As the leaf essential oils from E. citriodora had the most potent NO inhibitory activity in LPS-activated RAW264.7 macrophages, the essential oils were fractionated into Fractions A- H. We found that Fractions D, E, F, $\mathrm{G}$ and $\mathrm{H}$ significantly reduced $\mathrm{NO}$ generation to 63 , $62,42,37$ and $0.1 \%$, respectively, in LPS-activated RAW264.7 macrophages (Fig. 2a). Although fraction $\mathrm{H}$ exerts the best NO inhibitory activity, the yield of the fraction $\mathrm{H}(2.3 \%)$ is too low to test its biological activity. Therefore, fractions D, E, F and G were selected for further investigation. The NO inhibitory activity of Fractions $\mathrm{D}, \mathrm{E}, \mathrm{F}$ and $\mathrm{G}$ were confirmed in a dose response study, and Fractions $\mathrm{F}$ and $\mathrm{G}$ exert better NO inhibitory activity than Fractions D and E (Fig. 2b). In addition, Fractions $\mathrm{F}$ and $\mathrm{G}$ did not affect the cell viability at the concentration below $400 \mu \mathrm{g} / \mathrm{ml}$ (Fig. 2c). These results 

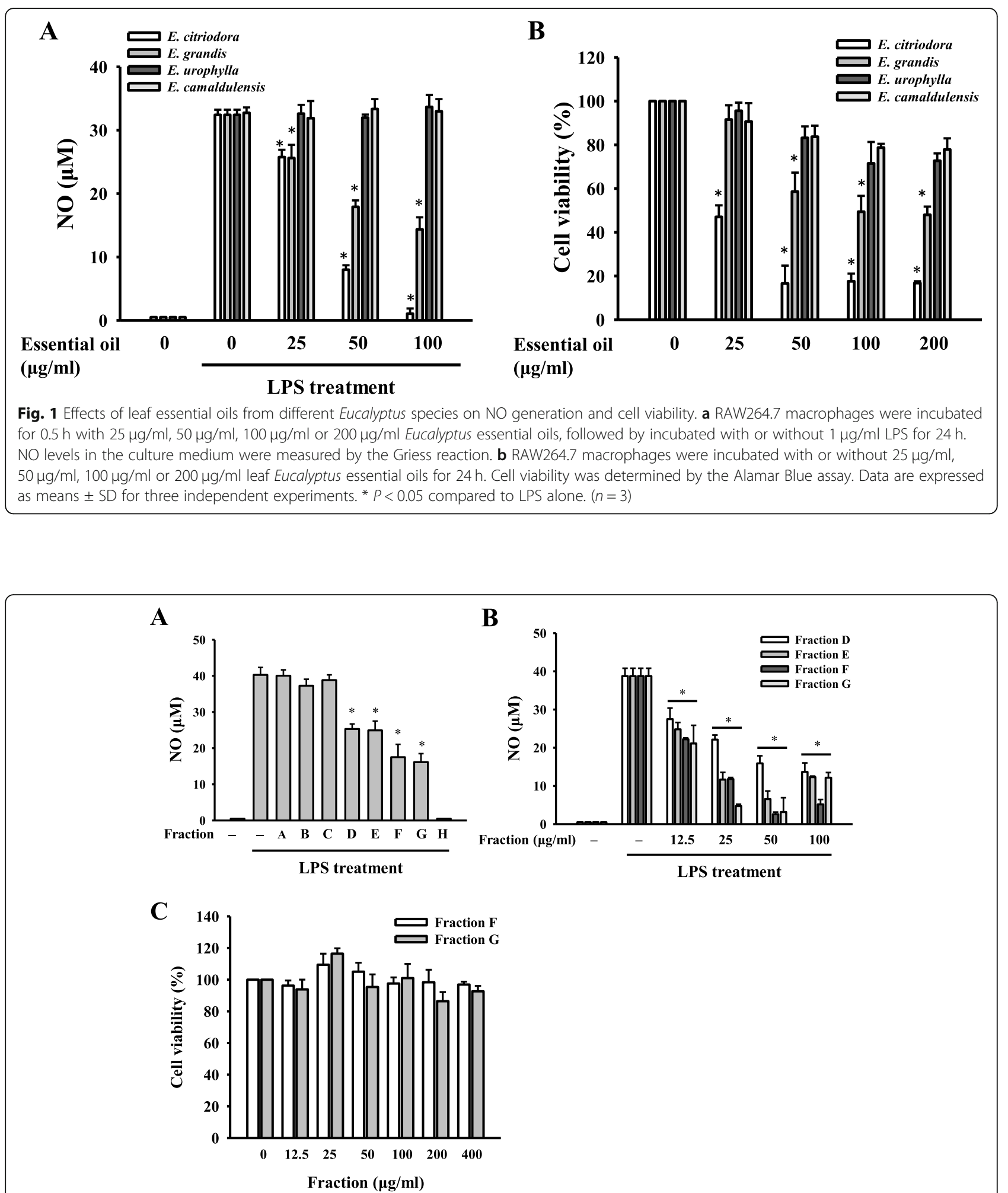

Fig. 2 Subfractions of E. citriodora leaf essential oils inhibited NO generation. (a) RAW264.7 macrophages were treated for $0.5 \mathrm{~h}$ with $100 \mu \mathrm{gg} / \mathrm{ml}$ Fractions $A, B, C, D, E, F, G$ and $H$, followed by incubation with or without $1 \mu \mathrm{g} / \mathrm{ml}$ LPS for $24 \mathrm{~h}$. NO production in the culture medium was measured by the Griess reaction. b RAW264.7 macrophages were treated for $0.5 \mathrm{~h}$ with $12.5 \mu \mathrm{g} / \mathrm{ml}, 25 \mu \mathrm{g} / \mathrm{ml}, 50 \mu \mathrm{g} / \mathrm{ml}$ or $100 \mu \mathrm{g} / \mathrm{ml} \mathrm{Fractions} \mathrm{D,}$ $\mathrm{E}$, F or G, followed by incubation with or without $1 \mu \mathrm{g} / \mathrm{ml} \mathrm{LPS}$ for $24 \mathrm{~h}$. NO production in the culture medium was measured by the Griess reaction. c RAW264.7 macrophages were incubated for $24 \mathrm{~h}$ with or without Fractions F and G. Cell viability was measured by the Alamar Blue assay. Data are expressed as means \pm SD of three independent experiments. ${ }^{*} P<0.05$ compared to LPS alone. $(n=3)$ 
indicated that Fractions $\mathrm{F}$ and $\mathrm{G}$ inhibited NO production was not due to the cytotoxicity. Furthermore, the chemical composition of Fractions F and G was analyzed by GC-MS, and the major compound in Fractions $\mathrm{F}$ and $\mathrm{G}$ was 4-methylsyringol (Table 1).

\section{Fraction $\mathrm{F}$ inhibited proinflammatory mediators}

Although Fractions F and G showed similar NO inhibitory activity, the yield of Fraction F (35.2\%) was better than Fraction G (18.1\%). Therefore, Fraction F was selected for further evaluation. We found that Fraction $\mathrm{F}$ at $12.5,25$ and $50 \mu \mathrm{g} / \mathrm{ml}$ reduced the expression levels of IL-6 to 55, 15 and 55\%, respectively, in LPS-activated RAW264.7 macrophages (Fig. 3a). Fraction F at 12.5, 25, 50 and $100 \mu \mathrm{g} / \mathrm{ml}$ reduced the expression levels of TNF$\alpha$ to $97,55,48$ and $53 \%$, respectively, in LPS-activated RAW264.7 macrophages (Fig. 3b). In addition, Fraction $\mathrm{F}$ also reduced the expression levels of COX-2 and iNOS in LPS-activated RAW264.7 macrophages (Fig. 3c).

\section{Fraction $\mathrm{F}$ reduced $\mathrm{NF}-\mathrm{kB}$ activation}

The transcription factor NF- $\mathrm{kB}$ plays a pivotal role in inflammation [18]. NF- $\mathrm{kB}$ inhibition suppresses NO generation and cytokine secretion in LPS-challenged macrophages [19]. Using NF- $\kappa B$ reporter cells (RAWBlue macrophages), we found that NF- $\kappa B$ transcriptional activity was reduced to $78,69,65$ and $55 \%$ by Fraction $F$ at $12.5,25,50$ and $100 \mu \mathrm{g} / \mathrm{ml}$, respectively, in LPSactivated macrophages (Fig. 4a). To confirm the NF- $\mathrm{KB}$ inhibitory activity of Fraction $F$, the effect of Fraction F on the phosphorylation levels of IKK- $\alpha$ and IкB- $\alpha$ in LPS-activated RAW264.7 macrophages was investigated [20]. We found that Fraction F inhibited the phosphorylation levels of IKK- $\alpha$ and IKB- $\alpha$ in LPS-activated RAW264.7 macrophages (Fig. 4b).
Fraction $\mathrm{F}$ reduced the phosphorylation levels of MAPK and PKC

It has been demonstrated that LPS increased the expression levels of inflammatory mediators via the MAPK and PKC signaling pathways in macrophages [19]. We examined the effect of Fraction $F$ on the phosphorylation levels of MAPK and PKC in LPS-activated macrophages. LPS increased the phosphorylation levels of ERK1/2, JNK1/2 and p38, and these effect were slightly reduced by Fraction F (Fig. 5a). In addition, LPS increased the phosphorylation levels of PKC- $\alpha, \mathrm{PKC}-\delta$, and PKC- $\varepsilon$, and these effect were significantly reduced by Fraction $\mathrm{F}$ (Fig. 5b).

\section{Discussion}

Inflammation is therapeutically controlled mainly by steroidal and nonsteroidal anti-inflammatory drugs. However, both cause several serious side effects. Current research has focused on the discovery of natural nonsteroidal anti-inflammatory drugs with strong therapeutic efficacy that induce minimal adverse reactions. In this study, of the four Eucalyptus species whose leaf essential oils we tested and compared, those from E. citriodora most effectively reduced the NO production induced by LPS in murine RAW264.7 macrophages. However, using a cell viability assay we found that the leaf essential oils of E. citriodora was toxic to the RAW264.7. To remove the toxic ingredients in the leaf essential oils of E. citriodora, the leaf essential oils were fractionated into Fractions A-H by a silica gel column. We found that Fractions $\mathrm{F}$ and $\mathrm{G}$ keep the anti-inflammatory activity and were not toxic to the Raw264.7 macrophages. When inflammation occurs, monocytes are attracted to chemokines, enter the lesion, and transformed into macrophages that undergo phagocytosis and release

Table 1 Chemical composition of Fractions F and G

\begin{tabular}{|c|c|c|c|c|c|}
\hline \multirow[t]{2}{*}{ Compound ID } & \multirow{2}{*}{$\begin{array}{l}\text { Kováts } \\
\text { retention } \\
\text { indices }^{a}\end{array}$} & \multirow{2}{*}{$\begin{array}{l}\text { Kováts } \\
\text { retention } \\
\text { indices }^{b}\end{array}$} & \multicolumn{2}{|c|}{ Concentration (\%) } & \multirow[t]{2}{*}{ Identificationc } \\
\hline & & & Fraction F & Fraction $G$ & \\
\hline Menthol & 1171 & 1172 & 4.6 & 17.6 & $\mathrm{MS}, \mathrm{KI}, \mathrm{ST}$ \\
\hline 4-hydroxy-Benzenemethanol & 1337 & 1337 & 24.4 & 2.2 & MS, KI, ST \\
\hline Citronellic acid & 1313 & 1311 & 12.7 & 2.4 & $\mathrm{MS}, \mathrm{Kl}, \mathrm{ST}$ \\
\hline 4-Methylsyringol & 1449 & 1451 & 41.3 & 25.7 & $\mathrm{MS}, \mathrm{Kl}, \mathrm{ST}$ \\
\hline trans, cis-Iridolactone & 1446 & 1446 & 7.6 & $-d$ & $\mathrm{MS}, \mathrm{KI}$ \\
\hline 14-hydroxy-a-Humulene & 1714 & 1714 & - & 17.5 & $\mathrm{MS}, \mathrm{KI}$ \\
\hline Manool & 2057 & 2057 & 1.8 & 0.8 & MS, Kl, ST \\
\hline 2-Phenyl ethyl anthranilate & 2126 & 2127 & 2.2 & 0.9 & MS, KI \\
\hline Citronellyl anthranilate & 2180 & 2181 & 1.1 & 0.5 & $\mathrm{MS}, \mathrm{Kl}, \mathrm{ST}$ \\
\hline Geranyl anthranilate & 2217 & 2215 & 1.1 & 0.6 & $\mathrm{MS}, \mathrm{Kl}, \mathrm{ST}$ \\
\hline
\end{tabular}

${ }^{a}$ Kováts retention indices on a DB-5 column with reference to $n$-alkanes [15].

${ }^{\mathrm{b}}$ Kováts retention indices, experimental: $\mathrm{n}$-alkanes (C9-C24) were used as reference points in the calculation of relative retention indices.

c MS, NIST and Wiley library spectra and the literature; KI, Kovats index; ST, authentic standard compounds.

${ }^{d}$ Not detected 
A

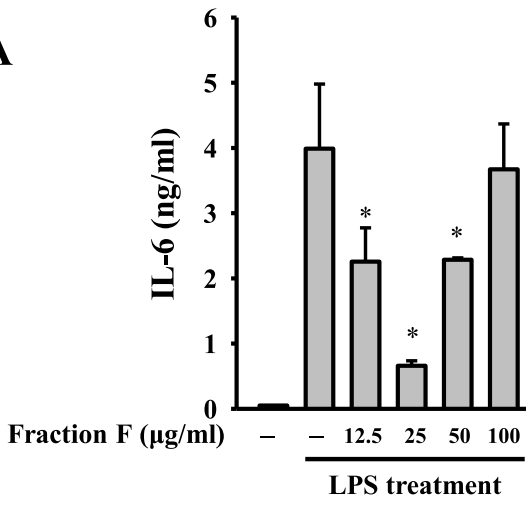

C
B

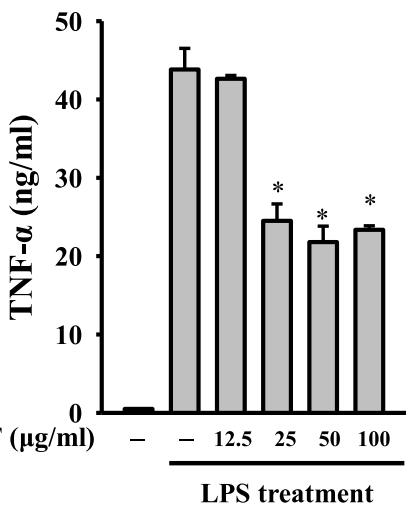

$\begin{array}{llllllllll}\text { Fraction F }(\mu \mathrm{g} / \mathrm{ml}) & 0 & 0 & 12.5 & 25 & 50 & 12.5 & 25 & 50\end{array}$

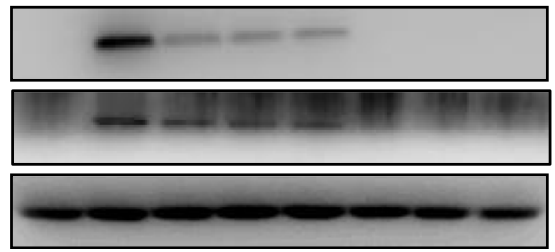

COX-2

iNOS

Actin

Fig. 3 Fraction F inhibited proinflammatory mediators. RAW264.7 macrophages were treated for $0.5 \mathrm{~h}$ with $12.5 \mu \mathrm{g} / \mathrm{ml} 25 \mu \mathrm{g} / \mathrm{ml}, 50 \mu \mathrm{g} / \mathrm{ml}$ or $100 \mathrm{\mu g} / \mathrm{ml}$ Fraction F, followed by incubation with or without $1 \mu \mathrm{g} / \mathrm{ml}$ LPS for $24 \mathrm{~h}$. The levels of IL-6 (a) and TNF-a (b) in the culture media were determined by ELISA. The expression levels of COX-2 and INOS in the cell lysates were measured by Western blot (c). Western blot results are representative of three different experiments. ELISA data are presented as means \pm SD of three independent experiments. ${ }^{*} P<0.05$ compared to LPS alone. $(n=3)$

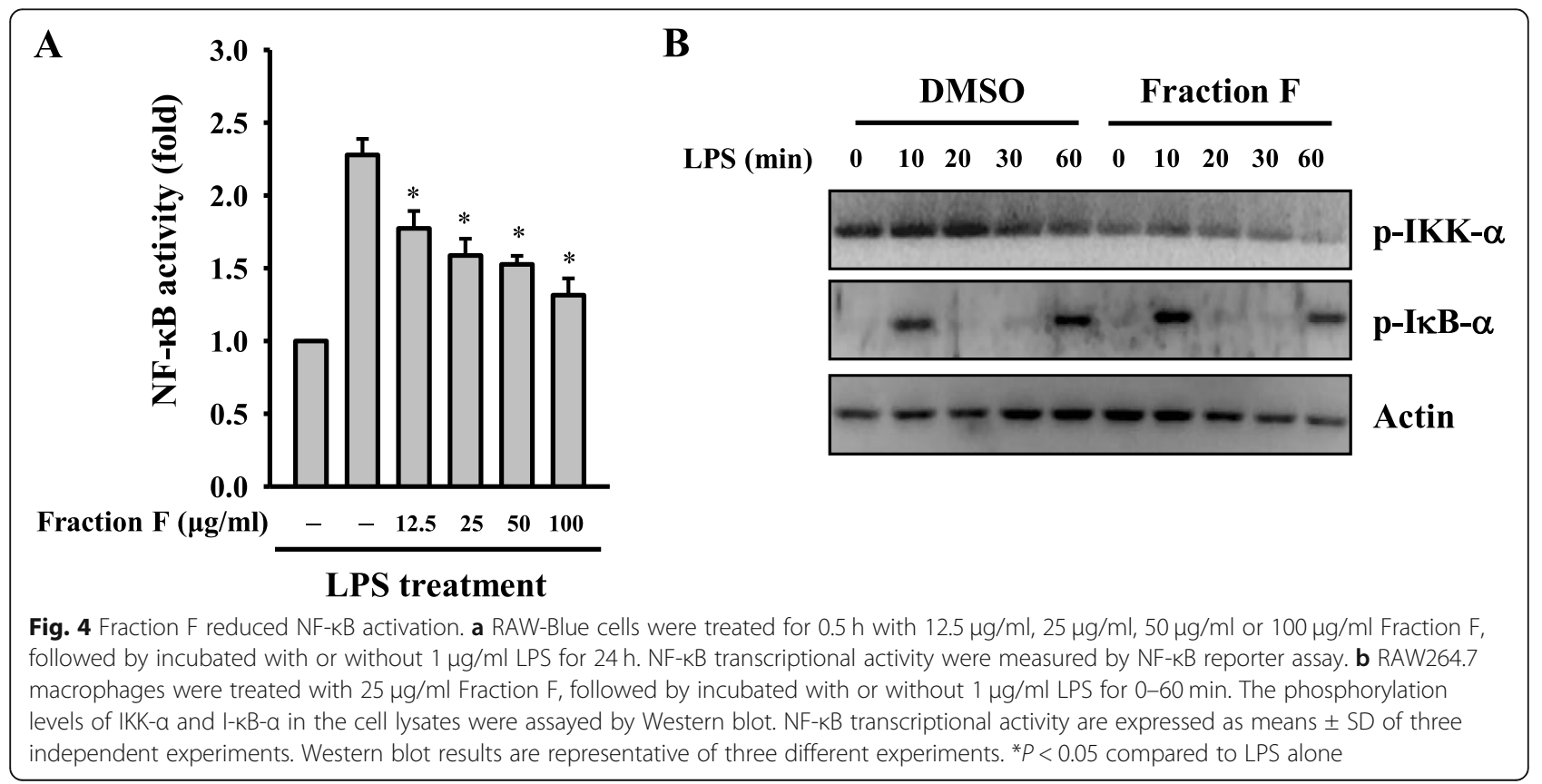




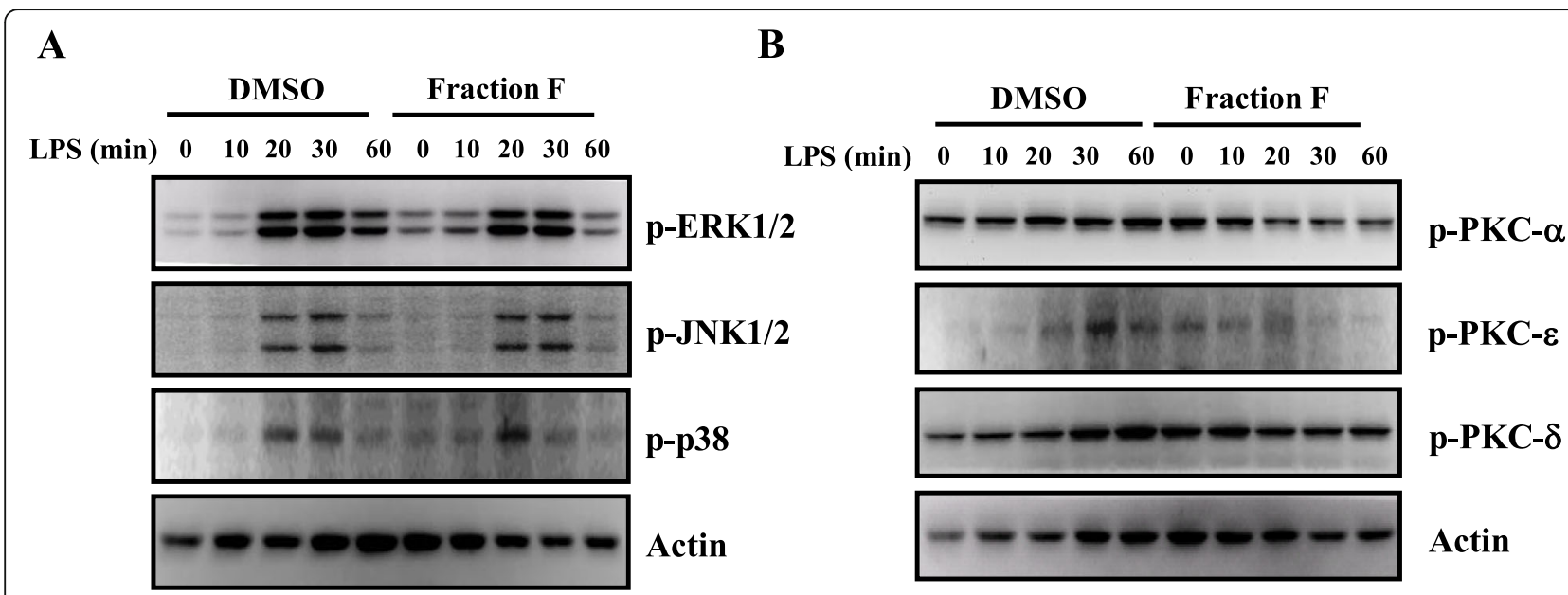

Fig. 5 Fraction F reduced the phosphorylation levels of MAPK and PKC. RAW264.7 macrophages were treated with $25 \mu \mathrm{g} / \mathrm{ml}$ Fraction F, followed by incubated with or without $1 \mu \mathrm{g} / \mathrm{ml}$ LPS for 0-60 min. The phosphorylation levels of ERK1/2, JNK1/2 and p38 (a), and phosphorylation levels of PKC- $a$, PKC- $\varepsilon$ and PKC- $\delta(\mathbf{b})$ in the cell lysates were assayed by Western blot

proinflammatory cytokines such as IL-6 and TNF- $\alpha$. It has been demonstrated that LPS induces proinflammatory cytokines through ERK1/2, JNK1/2 and p38 in macrophages $[21,22]$. In addition, LPS-mediated PKC activation induces the downstream signaling pathways such as MAPK $[23,24]$ or NF- $\mathrm{kB}[25]$, that regulate the expression of IL-1 $\beta$, IL-6, and TNF- $\alpha$ in macrophages. Here, Fraction $\mathrm{F}$ inhibited the phosphorylation levels of ERK1/2, p38, PKC- $\alpha$, PKC- $\varepsilon$ and PKC- $\delta$ as well as suppressed NF- $\kappa \mathrm{B}$ activation. However, Fraction $\mathrm{F}$ did not suppress JNK1/2 phosphorylation. These results suggest that Fraction $\mathrm{F}$ attenuated the inflammatory response in LPS-activated macrophages partially through inhibiting the activation of ERK1/2, p38, PKC- $\alpha, P K C-\varepsilon$, and PKC$\delta$ and $N F-\kappa B$.

Notably, although Fraction F inhibited LPS-induced IL-6 secretion at 12.5 and $25 \mu \mathrm{g} / \mathrm{ml}$; the IL- 6 inhibitory activity was loss at higher concentration 50 and $100 \mu \mathrm{g} /$ $\mathrm{ml}$ (Fig. 3a). The contradictory effect of Fraction F in IL6 secretion may due to the complicated chemical composition. Chemical composition analysis showed that Fraction F contained 9 compounds: 4-methylsyringol (41.3\%), 4-hydroxyl-Benzenemethanol (24.4\%), Citronellic acid (12.7\%), trans, cis-Iridolactone (7.6\%), Menthol (4.6\%), 2-Phenyl ethyl anthranilate (2.2\%), Manool (1.8\%), Citronellyl anthranilate (1.1\%) and Citronellyl tiglate (1.1\%) (Table 1). Although 4-methylsyringol, 4hydroxyl-Benzenemethanol and Citronellic acid were the major compounds in Fraction F, there were no biological activity reported yet for these three compounds. Menthol is the fourth most abundant compound in Fraction $\mathrm{F}$, and it has been reported to exert anti-inflammatory activity by suppressing the production of $\mathrm{LTB}_{4}, \mathrm{PGE}_{2}$ and IL-1 $\beta$ in LPS-activated human monocytes [26]. In addition, Shahid et al. demonstrated that the level of urinary menthol was significantly reduced in interstitial cystitis patients compared to healthy controls [27]. Menthol inhibited the expression levels of TNF- $\alpha$, IL-6, IL$1 \beta$ and CCL3 in LPS-activated RAW264.7 macrophages through reducing the activation of $\mathrm{AKT}$ and NF-KB [27]. These results suggest that Menthol (4.6\% in fraction F) should be one of the bioactive compound in fraction $F$ that response for the anti-inflammatory activity; however, we cannot rule out the possibility that the antiinflammatory activity of fraction $\mathrm{F}$ was resulted from the synergistic effect between essential oil components.

The biological functions of Eucalyptus leaf essential oils have been extensively investigated, including antimicrobial, antiviral, antidiabetic, antioxidant, antitumor and anti-inflammatory activities [28]. It has been demonstrated that $E$. citriodora essential oil exerts the antiinflammatory and analgesic effects on formol-induced edema and acetic acid-induced abdominal cramps in Wistar rats, and the major compound of the E. citriodora essential oil is citronellal [29]. Juergens et al. demonstrated that 1,8-cineole, isolated from Eucalyptus essential oil, inhibits the production of TNF- $\alpha$, IL-1 $\beta$, leukotriene B4 and thromboxane B2 in LPS-activated human blood monocytes [30]. In addition, E. globulus oil reduces LPS-induced chronic bronchitis and mucin hypersecretion in rats; however, the active compound was not identified yet [31].

Based on the cell viability assay, Fraction $F$ was nontoxic to the RAW264.7 macrophages under the experimental condition (12.5-400 $\mu \mathrm{g} / \mathrm{ml})$. However, Manool, a minor compound in the Fraction F, has been reported to exhibit higher cytotoxic activity against human cervical adenocarcinoma HeLa cells (IC50 = 6.7 $\pm 1.1 \mu \mathrm{g} / \mathrm{ml}$ ) and human glioblastoma U343 cells $(\mathrm{IC} 50=6.7 \pm 1.2 \mu \mathrm{g} / \mathrm{ml}$ ) than for the normal Chinese hamster lung fibroblasts 


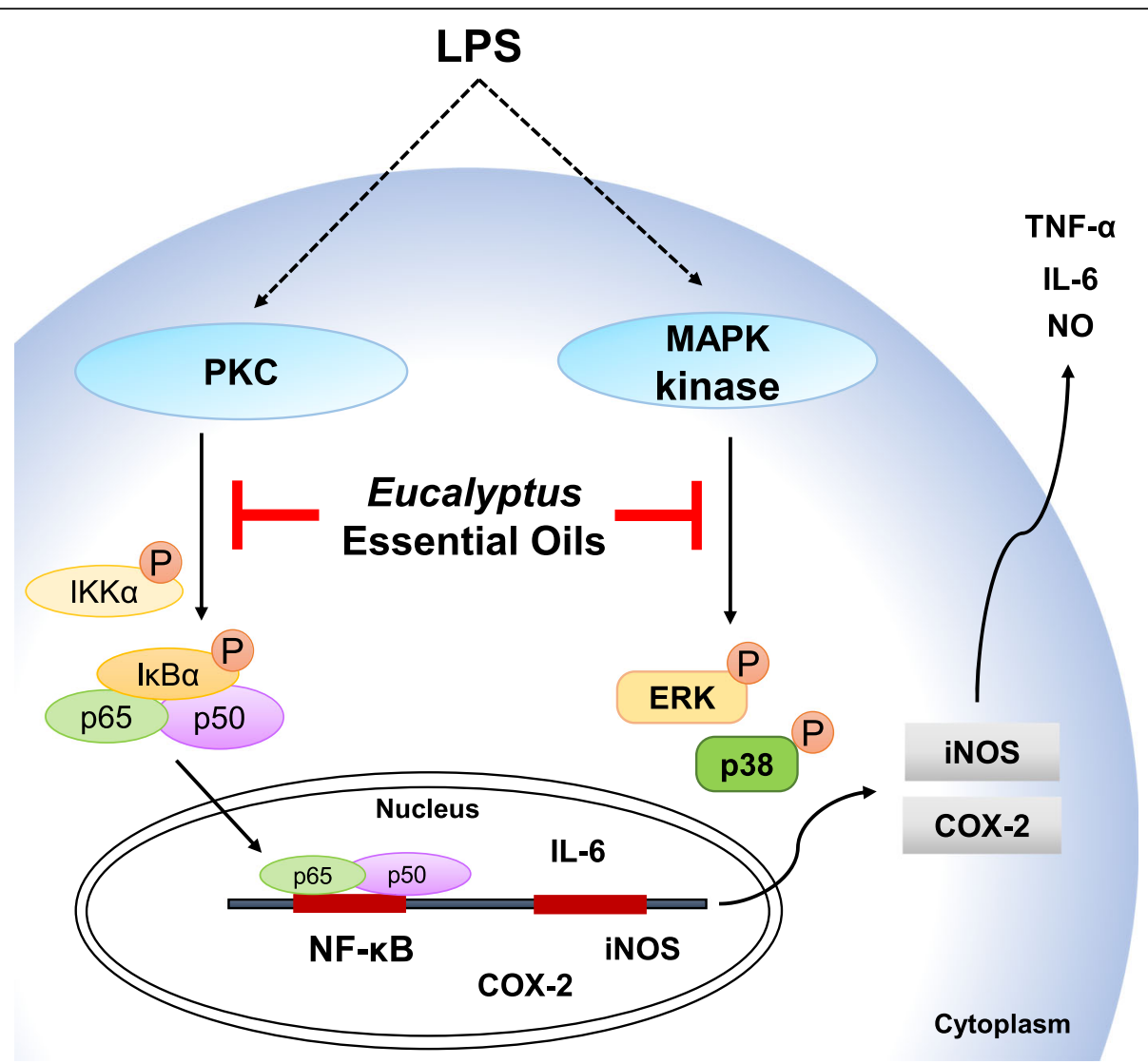

Fig. 6 Overview of the putative mechanisms by which E. citriodora leaf essential oils attenuated the inflammatory response in macrophage. $E$. citriodora leaf essential oils inhibit LPS-induced inflammatory response in RAW264.7 macrophages by reducing the ERK1/2/P38 and PKC/NF-KB signaling pathways

V79 cells $(\mathrm{IC} 50=49.3 \pm 3.3 \mu \mathrm{g} / \mathrm{ml})$ [32]. Although Manool in Fraction F only $1.8 \%$, the possible toxic effect of Fraction $\mathrm{F}$ should be further investigation. In addition, the anti-inflammatory activity of Fraction $\mathrm{F}$ in vivo, and the optimization of the administration routes, dosages and application intervals of Fraction $\mathrm{F}$ in animal study need further investigation.

\section{Conclusions}

Essential oils extracted from Eucalyptus leaves have antioxidant, antimicrobial, immunoregulatory, analgesic and anti-inflammatory properties. While conventional NSAIDs cause fewer serious side effects than their steroidal counterparts, they may nonetheless induce GI bleeding, distress, inflammation and ulceration in many patients, thereby reducing therapeutic compliance and treatment efficacy [33-35]. Here, we investigated the anti-inflammatory activity of the leaf essential oils from four Eucalyptus tree species in LPS-activated RAW264.7 macrophage. We demonstrated that the leaf essential oils from E. citriodora exert best NO inhibitory activity than other species. We further demonstrated that the Fraction $\mathrm{F}$ of E. citriodora leaf essential oils inhibited the expression levels of TNF- $\alpha$, IL-6, NO, iNOS and COX-2 through reducing PKC/NF- $K B$ and ERK1/2/p38 in the LPS-activated RAW264.7 macrophages (Fig. 6). These results suggested that leaf essential oils from E. citriodora can be developed as a anti-inflammatory agent in the future.

\section{Abbreviations}

ANOVA: Analysis of variance; BSA: Bovine serum albumin; CC: Column chromatography; COPD: Chronic obstructive pulmonary disease;

COX2: Cyclooxygenase II; ECL: Enhanced chemiluminescence; ELISA: Enzymelinked immunosorbent assay; ERK: Extracellular signal-related kinase;

FBS: Fetal bovine serum; FCS: Fetal calf serum; FID: Flame ionization detector; GC: Gas chromatography; IKK: IKB kinase; IL: Interleukin; iNOS: Inducible nitric oxide synthase; JNK: c-Jun N-terminal kinase; LPS: Lipopolysaccharides; MAPK: Mitogen-activated protein kinase; MS: Mass spectrometry; NFKB: Nuclear factor kappa-light-chain-enhancer of activated B cells; NIST: National Institutes of Science and Technology; NO: Nitric oxide; p38: p38 mitogen-activated protein kinase; PBS: Phosphate-buffered saline; PKC: Protein kinase C; PVDF: Polyvinylidene fluoride;

RIPA: Radioimmunoprecipitation assay; ROS: Reactive oxygen species; RPMI: Roswell Park Memorial Institute; SD: Standard deviation; SDSPAGE: Sodium dodecyl sulfate-polyacrylamide gel electrophoresis; SEAP: Secreted embryonic alkaline phosphatase; TLC: Thin-layer chromatography; TNF: Tumor necrosis factor; WB: Western blot

Acknowledgements Not Applicable 


\section{Authors' contributions}

$\mathrm{CLH}$ and KFH conceived and designed the experiments. CLH, LHL and YCW performed the experiment and analyzed the data. TCJ wrote the paper. LHL and KFH revised the manuscript. TCJ provided the grant and manuscript editing. All authors read and approved of the final manuscript.

\section{Funding}

This work was supported by grants from the Ministry of Science and Technology of Taiwan (No. MOST 106-2311-B-029-005 and No. MOST 1072311-B-029-002), Taiwan. These supports were for the design and execution of the experiment.

\section{Availability of data and materials}

All data of this study is included in the manuscript.

\section{Ethics approval and consent to participate}

Not applicable.

\section{Consent for publication}

All authors mentioned agreed for the publication of the manuscript.

\section{Competing interests}

The authors declare that they have no competing interests.

\section{Author details}

'Division of Wood Cellulose, Taiwan Forestry Research Institute, Taipei, Taiwan. ${ }^{2}$ Department of Laboratory Medicine, Linsen, Chinese Medicine and Kunming Branch, Taipei City Hospital, Taipei, Taiwan. ${ }^{3}$ Department of Pathology, Tri-Service General Hospital, National Defense Medical Center, Taipei, Taiwan. ${ }^{4}$ EMA program in College of Bioresources, National Ilan University, Ilan, Taiwan. ${ }^{5}$ Department of Biotechnology and Animal Science, National Ilan University, llan, Taiwan. ${ }^{6}$ Department of Medical Research, China Medical University Hospital, China Medical University, Taichung, Taiwan. ${ }^{7}$ Department of Animal Science and Biotechnology, Tunghai University, No. 1727, Sec. 4, Taiwan Blvd., Xitun Dist, Taichung City 40704, Taiwan.

\section{Received: 11 March 2020 Accepted: 22 June 2020}

\section{Published online: 29 June 2020}

\section{References}

1. Cheng S-S, Huang C-G, Chen Y-J, Yu J-J, Chen W-J, Chang S-T. Chemical compositions and larvicidal activities of leaf essential oils from two eucalyptus species. Bioresour Technol. 2009;100(1):452-6.

2. Silva J, Abebe W, Sousa SM, Duarte VG, Machado MIL, Matos FJA. Analgesic and anti-inflammatory effects of essential oils of Eucalyptus. J Ethnopharmacol. 2003;89(2-3):277-83.

3. Sadlon AE, Lamson DW. Immune-modifying and antimicrobial effects of Eucalyptus oil and simple inhalation devices. Altern Med Rev. 2010;15(1):3347.

4. Habila N, Agbaji AS, Ladan Z, Bello IA, Haruna E, Dakare MA, Atolagbe TO. Evaluation of in vitro activity of essential oils against Trypanosoma brucei brucei and Trypanosoma evansi. J Parasitol Res. 2010;2010.

5. Clemente MA, de Oliveira Monteiro CM, Scoralik MG, Gomes FT, de Azevedo Prata MC, Daemon E. Acaricidal activity of the essential oils from Eucalyptus citriodora and Cymbopogon nardus on larvae of Amblyomma cajennense (Acari: Ixodidae) and Anocentor nitens (Acari: Ixodidae). Parasitol Res. 2010; 107(4):987-92.

6. Bachir RG, Benali M. Antibacterial activity of the essential oils from the leaves of Eucalyptus globulus against Escherichia coli and Staphylococcus aureus. Asian Pac J Trop Biomed. 2012;2(9):739-42.

7. Salem MZM, Elansary HO, Ali HM, El-Settawy AA, Elshikh MS, Abdel-Salam EM, Skalicka-Wozniak K. Bioactivity of essential oils extracted from Cupressus macrocarpa branchlets and Corymbia citriodora leaves grown in Egypt. BMC Complement Altern Med. 2018;18(1):23.

8. Siramon P, Ohtani Y. Antioxidative and antiradical activities of \&ltti\&gt: Eucalyptus camaldulensis\&lt;/i\&gt; leaf oils from Thailand. J Wood Sci. 2007; 53(6):498-504

9. Serhan CN, Savill J. Resolution of inflammation: the beginning programs the end. Nat Immunol. 2005;6(12):1191-7.

10. Conti P, Shaik-Dasthagirisaeb Y. Atherosclerosis: a chronic inflammatory disease mediated by mast cells. Cent Eur J Immunol. 2015;40(3):380-6.
11. Yuan T, Yang T, Chen H, Fu D, Hu Y, Wang J, Yuan Q, Yu H, Xu W, Xie X New insights into oxidative stress and inflammation during diabetes mellitus-accelerated atherosclerosis. Redox Biol. 2018;20:247-60.

12. Bektas A, Schurman SH, Sen R, Ferrucci L. Human T cell immunosenescence and inflammation in aging. J Leukoc Biol. 2017;102(4):977-88.

13. Jaworski T, Lechat B, Demedts $D$, Gielis L, Devijver $H$, Borghgraef $P$, Duimel $H$ Verheyen F, Kugler S, Van Leuven F. Dendritic degeneration, neurovascular defects, and inflammation precede neuronal loss in a mouse model for taumediated neurodegeneration. Am J Pathol. 2011;179(4):2001-15.

14. Wang D, DuBois RN. Immunosuppression associated with chronic inflammation in the tumor microenvironment. Carcinogenesis. 2015;36(10): 1085-93.

15. Adams RP. Identification of essential oil components by gas chromatography/Quadrupole mass spectroscopy. 4rd ed. Carol Stream: Allured; 2007.

16. Liao PC, Chien SC, Ho CL, Wang El, Lee SC, Kuo YH, Jeyashoke N, Chen J, Dong WC, Chao LK, et al. Osthole regulates inflammatory mediator expression through modulating NF-kappaB, mitogen-activated protein kinases, protein kinase $C$, and reactive oxygen species. J Agric Food Chem. 2010;58(19):10445-51.

17. Li LH, Ju TC, Hsieh CY, Dong WC Chen WT, Hua KF, Chen WJ. A synthetic cationic antimicrobial peptide inhibits inflammatory response and the NLRP3 inflammasome by neutralizing LPS and ATP. PLOS One. 2017;12(7): e0182057.

18. Fan X, Zhang Y, Dong H, Wang B, Ji H, Liu X. Trilobatin attenuates the LPSmediated inflammatory response by suppressing the NF-kappaB signaling pathway. Food Chem. 2015;166:609-15.

19. Chao LK, Liao PC, Ho CL, Wang El, Chuang CC, Chiu HW, Hung LB, Hua KF. Anti-inflammatory bioactivities of honokiol through inhibition of protein kinase C, mitogen-activated protein kinase, and the NF-kappaB pathway to reduce LPS-induced TNFalpha and NO expression. J Agric Food Chem. 2010;58(6):3472-8

20. Baeuerle PA. IkappaB-NF-kappaB structures: at the interface of inflammation control. Cell. 1998;95(6):729-31.

21. Hambleton J, Weinstein SL, Lem L, Defranco AL. Activation of c-Jun Nterminal kinase in bacterial lipopolysaccharide-stimulated macrophages. Proc Natl Acad Sci U S A. 1996;93(7):2774-8.

22. Schumann RR, Pfeil D, Lamping $N$, Kirschning C, Scherzinger G, Schlag $P$, Karawajew L, Herrmann F. Lipopolysaccharide induces the rapid tyrosine phosphorylation of the mitogen-activated protein kinases erk-1 and p38 in cultured human vascular endothelial cells requiring the presence of soluble CD14. Blood. 1996;87(7):2805-14.

23. Werlen G, Jacinto E, Xia Y, Karin M. Calcineurin preferentially synergizes with PKC-theta to activate JNK and IL-2 promoter in T lymphocytes. EMBO J. 1998:17(11):3101-11.

24. Puente $\mathrm{LG}$, Stone JC, Ostergaard HL. Evidence for protein kinase Cdependent and -independent activation of mitogen-activated protein kinase in T cells: potential role of additional diacylglycerol binding proteins. J Immunol. 2000;165(12):6865-71.

25. Sun Z, Arendt CW, Ellmeier W, Schaeffer EM, Sunshine MJ, Gandhi L, Annes J, Petrzilka D, Kupfer A, Schwartzberg PL, et al. PKC-theta is required for TCRinduced NF-kappaB activation in mature but not immature T lymphocytes. Nature. 2000:404(6776):402-7.

26. Juergens UR, Stober M, Vetter $H$. The anti-inflammatory activity of Lmenthol compared to mint oil in human monocytes in vitro: a novel perspective for its therapeutic use in inflammatory diseases. Eur J Med Res. 1998:3(12):539-45.

27. Shahid M, Lee MY, Yeon A, Cho E, Sairam V, Valdiviez L, You S, Kim J. Menthol, a unique urinary volatile compound, is associated with chronic inflammation in interstitial cystitis. Sci Rep. 2018:8(1):10859.

28. Dhakad AK, Pandey W, Beg S, Rawat JM, Singh A. Biological, medicinal and toxicological significance of Eucalyptus leaf essential oil: a review. J Sci Food Agric. 2018;98(3):833-48.

29. Gbenou JD, Ahounou JF, Akakpo HB, Laleye A, Yayi E, Gbaquidi F, BabaMoussa L, Darboux R, Dansou P, Moudachirou M, et al. Phytochemical composition of Cymbopogon citratus and Eucalyptus citriodora essential oils and their anti-inflammatory and analgesic properties on Wistar rats. Mol Biol Rep. 2013:40(2):1127-34.

30. Juergens UR, Stober M, Vetter H. Inhibition of cytokine production and arachidonic acid metabolism by eucalyptol (1.8-cineole) in human blood monocytes in vitro. Eur J Med Res. 1998;3(11):508-10. 
31. Lu XQ, Tang FD, Wang Y, Zhao T, Bian RL. Effect of Eucalyptus globulus oil on lipopolysaccharide-induced chronic bronchitis and mucin hypersecretion in rats. Zhongguo Zhong Yao Za Zhi. 2004;29(2):168-71.

32. de Oliveira PF, Munari CC, Nicolella HD, Veneziani RC, Tavares DC. Manool, a Salvia officinalis diterpene, induces selective cytotoxicity in cancer cells. Cytotechnology. 2016;68(5):2139-43.

33. Laine L. Gastrointestinal effects of NSAIDs and coxibs. J Pain Symptom Manag. 2003;25(2 Suppl):S32-40.

34. Butt JH, Barthel JS, Hosokawa MC, Moore RA. NSAIDs: a clinical approach to the problems of gastrointestinal side-effects. Aliment Pharmacol Ther. 1988; 2(Suppl 1):121-9.

35. Sheen CL, MacDonald TM. Gastrointestinal side effects of NSAIDs pharmacoeconomic implications. Expert Opin Pharmacother. 2002;3(3):265-9.

\section{Publisher's Note}

Springer Nature remains neutral with regard to jurisdictional claims in published maps and institutional affiliations.

Ready to submit your research? Choose BMC and benefit from:

- fast, convenient online submission

- thorough peer review by experienced researchers in your field

- rapid publication on acceptance

- support for research data, including large and complex data types

- gold Open Access which fosters wider collaboration and increased citations

- maximum visibility for your research: over $100 \mathrm{M}$ website views per year

At BMC, research is always in progress.

Learn more biomedcentral.com/submissions 